\title{
Thimerosal Dalam Vaksin, Suatu Tinjauan Pustaka
}

\author{
Lina Herliana Soemara
}

Thimerosal memiliki risiko potensial yang rendah terhadap gangguan perkembangan syaraf pada bayi. Risiko kematian dan kesakitan karena penyakit yang dapat dicegah dengan imunisasi sudah diketahui serta risiko kontaminasi vaksin multidosis jauh di atas risiko potensial oleh thimerosal yang masih sebatas teori. Walaupun demikian, besarnya opini masyarakat yang menentang pemakaian merkuri dalam bentuk apapun, menyebabkan WHO dan badan/organisasi lain di dunia memulai proses untuk mengurangi dan menghilangkan thimerosal dari vaksin. Dalam jangka pendek, dilakukan modifikasi strategi vaksinasi yang akan mengurangi paparan terhadap thimerosal, usahausaha akan dipusatkan pada teknologi baru pemberian vaksin, pengawet alternatif dan vaksin kombinasi, yang akan mengurangi dan akhirnya sebagai sasaran akhir menghilangkan thimerosal dari vaksin.

Kata kunci: thimerosal, pengawet, vaksin multidosis

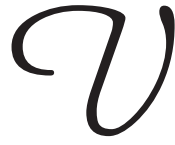

aksinasi merupakan intervensi kesehatan yang paling cost-effective untuk mencegah dan memberantas penyakit menular; smallpox (cacar) dapat dibasmi dari muka bumi karena vaksinasi, polio juga sudah terbasmi dari benua Amerika dan wilayah Pasifik Barat karena kegiatan vaksinasi. Selama ini vaksin telah berjasa melindungi manusia dari penyakit dan dari kecacatan karena penyakit.

Beberapa publikasi ilmiah pada tahun $1998^{1}$ memunculkan hipotesis kemungkinan adanya hubungan antara vaksin dengan autisme, pada saat yang hampir bersamaan masyarakat mulai menaruh perhatian terhadap paparan merkuri dalam kehidupan sehari-hari, yang juga dihubungkan dengan kejadian autisme yang meningkat akhir-akhir ini.

Pada akhir Juni tahun 1999, FDA (Food and Drug Administration) dari Amerika mengungkapkan bahwa sejumlah bayi yang menerima vaksin multidosis mengandung thimerosal mungkin terpapar terhadap sejumlah merkuri yang melebihi ketentuan pemerintah

\footnotetext{
Alamat korespondensi:

Dr. Lina Herliana Soemara.

Divisi Surveilans \& Epidemiologi P.T Bio Farma, Jalan Pasteur no. 28, Bandung.

Tel. 022-2033755/2037430, Fax. 2037430/2041306.

E-mail: lina.soemara@biofarma.co.id
}

federal. ${ }^{2}$ Beberapa badan federal, The American Academy of Pediatrics (AAP), badan internasional dan produsen vaksin telah memberikan respons dengan cepat terhadap kekhawatiran ini. ${ }^{3}$ Walaupun thimerosal dari vaksin tidak terbukti membahayakan manusia, namun FDA menganjurkan produsen vaksin agar mengurangi atau bahkan mengganti thimerosal di dalam vaksin dalam rangka mengurangi paparan terhadap merkuri.

Dalam tinjauan pustaka ini akan dikemukakan fakta-fakta serta pendapat badan internasional perihal ini agar menjadi pegangan bagi teman sejawat dalam tugas sehari-hari yang berhubungan dengan orang tua pasien yang mengkhawatirkan akibat pemberian imunisasi.

\section{Apa yang dimaksud dengan thimerosal?}

Thimerosal atau disebut juga thiomersal atau mercurothiolate, adalah pengawet yang sangat efektif yang mengandung merkuri, dan telah dipergunakan dalam pembuatan vaksin sejak tahun 1930-an. Efek samping yang dilaporkan berupa sensitivitas kulit yaitu kemerahan yang kejadiannya sangat jarang.

Merkuri dalam bentuk organik sebagai methylmercury banyak terdapat dalam lingkungan kehidupan 
manusia, antara lain, ikan dari laut yang tercemar, mainan, produk makanan dan sebagainya. Paparan terhadap methyl-mercury pada ibu hamil di Irak dan Jepang telah dilaporkan dapat menyebabkan kelainan neurologi yaitu delayed development pada bayi dalam rahim. ${ }^{4}$

\section{Mengapa Thimerosal dipakai di dalam vaksin?}

Thimerosal dipakai sebagai pengamanan terhadap kontaminasi bakteri dan mikro-organisme lain terutama pada vial multi-dosis yang sudah dibuka. ${ }^{4,5}$ Sebelum thimerosal dipasarkan di Amerika, telah dilaksanakan uji keamanan pada hewan maupun pada manusia. Thimerosal sangat efektif untuk membunuh bakteri dalam beberapa jenis vaksin dan untuk mencegah kontaminasi bakteri. Pernah terjadi wabah penyakit karena kontaminasi vial vaksin multi-dosis baik di Amerika maupun di negara lain, sebagai contoh pada tahun 1995, tiga orang bayi di India meninggal karena toxic shock syndrome setelah pemberian vaksin campak yang terkontaminasi.

\section{Apakah semua vaksin mengandung Thimerosal?}

Tidak semua vaksin mengandung thimerosal, vaksin yang berisi mikro-organisme hidup tidak mengandung thimerosal, misalnya MMR, OPV, campak, dan BCG, demikian juga vaksin $\mathrm{HB}$ single-dose dari beberapa produsen sudah tidak menggunakan thimerosal, vaksin yang beredar di Indonesia yang mengandung thimerosal antara lain DPT, DT, TT, dan Hepatitis-B.

\section{Berapa kandungan merkuri dalam vaksin?}

Thimerosal mengandung 49,6\% merkuri menurut beratnya, di dalam tubuh manusia dipecah menjadi ethylmercury dan thiosalicylate. Kadar yang diperbolehkan menurut WHO adalah ${ }^{6}$ untuk vaksin bakteri 0,005$0,02 \%$ dan vaksin Hepatitis-B $<0,012 \%$.

\section{Bagaimana menghitung kadar Merkuri $(\mathrm{Hg})$ dalam vaksin?}

Kadar thimerosal dalam vaksin Bio Farma adalah

$$
\begin{aligned}
& 0,01 \% \text {, berarti: } \\
& \quad=0,01 \mathrm{gram} / 100 \mathrm{ml} \\
& =10^{-2} \times 10^{6} \mathrm{ug} / 10^{2} \mathrm{ml} \\
& =10^{4} \mathrm{ug} / 10^{2} \mathrm{ml} \\
& =100 \mathrm{ug} / \mathrm{ml} \\
& =50 \mathrm{ug} / 0,5 \mathrm{ml}
\end{aligned}
$$

Kadar merkuri adalah 49,6\% dari berat thimerosal yaitu $25 \mathrm{ug} / 0,5 \mathrm{ml}$ atau $25 \mathrm{ug} /$ dosis vaksin.

Dengan demikian, maka jumlah kumulatif paparan merkuri pada bayi berusia 6 bulan akan mencapai 150 ug, dengan perhitungan sebagai berikut:

tiga dosis DPT $=3 \times 25 \mathrm{ug}=75 \mathrm{ug}$

tiga dosis $\mathrm{HB}=3 \times 25 \mathrm{ug}=75 \mathrm{ug}$

Jadi total merkuri $(\mathrm{Hg})$ yang masuk ke dalam tubuh bayi adalah 150 ug.

\section{Berapakah nilai paparan merkuri yang masih aman? ${ }^{2}$}

Beberapa badan internasional menetapkan nilai paparan yang berbeda

Bila kita mengambil nilai dari WHO ${ }^{4}$ maka pada bayi

Tabel 1. Kadar keamanan Merkuri dalam Makanan

\begin{tabular}{lc} 
Badan /agency & Nilai methyl mercury $(\mathrm{ug} / \mathrm{kg} / \mathrm{hari})$ \\
\hline EPA & 0,1 \\
FDA & 0,4 \\
ATSDR & 0,3 \\
WHO & $3,3 \mathrm{ug} / \mathrm{kg} /$ minggu
\end{tabular}

\footnotetext{
Catatan:

$\mathrm{EPA}=$

FDA $\quad$ food and drug administration

ATSDR = agency for toxic substances and disease registry

$\mathrm{WHO}=$ world health organization
}

dengan berat badan di atas $5^{\text {th }}$ percentile, batas total paparan merkuri antara lahir sampai dengan 14 minggu adalah 159 ug.

Institute of Vaccine Safety (IVS) menyatakan bahwa sekarang ini belum ada bukti bahwa jumlah thimerosal dalam vaksin menyebabkan bahaya kecuali reaksi alergi 
yang ringan, namun hendaknya risiko potensial ini dikurangi seminimal mungkin. ${ }^{7}$

Faktor-faktor yang mempengaruhi timbulnya keracunan terhadap merkuri ${ }^{7}$

- Dosis, makin besar dosis yang masuk makin besar risiko keracunan.

- Bentuk merkuri, methyl mercury sudah diketahui menimbulkan efek keracunan, apakah tingkat racun ethyl mercury sama dengan methyl mercury? Belum ada yang dapat memastikan.

- Apakah pemberian sekaligus, intermiten, atau paparan sekaligus dalam kadar tinggi lebih berbahaya dibandingkan kadar kecil seharihari. $^{2}$

- Umur, yang paling sensitif terhadap paparan merkuri adalah bayi dalam rahim dan anak $\leq 14$ tahun. ${ }^{5}$

- Berat badan, makin kecil berat badan bayi, makin rendah ambang keamanan terhadap merkuri.

- Paparan merkuri lain.

- Metabolisme dan excretion rate, terdapat perbedaan antar individu.

- $\quad$ Predisposisi genetik.

\section{Pernyataan bersama perihal menghilangkan thimerosal dari vaksin. ${ }^{3}$}

Pada 22 Juni 2000, beberapa badan / organisasi di Amerika Serikat mengeluarkan pernyataan bersama untuk menghilangkan thimerosal dari vaksin. Badan/ organisasi yang terlibat adalah:

AAFP - The American Academy of Family Physicians, AAP - The American Academy of Pediatrics,

ACIP - The Advisory Committee on Immunization Practices,

PHS - The United States Public Health Services

Isi pernyataannya sebagai berikut

- Adanya risiko secara potensial dari merkuri, dan menghilangkan thimerosal dari vaksin dimungkinkan, maka thimerosal hendaknya dihilangkan dari vaksin secepatnya. Walaupun demikian, tak ada bukti yang meyakinkan tentang bahaya thimerosal dosis rendah yang ada dalam vaksin.

- Sampai tersedianya vaksin yang bebas thimerosal, penggunaan vaksin yang mengandung thimerosal masih dapat diterima.

\section{Bagaimana hasil penelitian pengaruh vaksin yang mengandung thimerosal terhadap kesehatan? ${ }^{8}$}

1. National Institute of Health bekerja sama dengan University of Rochester dan Bethesda Naval Hospital, melakukan studi untuk menetapkan berapa banyak merkuri dapat ditemukan dalam darah bayi setelah terpapar vaksin yang mengandung thimerosal. Data awal studi ini menunjukkan kadar merkuri dalam darah $<2 \mathrm{ug} / \mathrm{L}$, kadar tersebut menurut para pakar berada di bawah kadar dasar.

2. CDC menggunakan database yang luas dan International Classification of Disease Codes (ICD9) untuk menyaring kemungkinan hubungan antara paparan terhadap thimerosal dalam vaksin dengan sejumlah gangguan neurologi, perkembangan dan ginjal. Hasilnya, tak ada hubungan antara paparan thimerosal dari 12 antara 17 ICD neurologi yang diteliti.

\section{Apakah thimerosal menyebabkan autisme ${ }^{3}$}

Pada saat ini, tidak ada data yang menunjukkan bahwa thimerosal dalam vaksin meningkatkan risiko berkembangnya autisme atau gangguan tingkah laku yang lain. Namun, karena kekhawatiran orang tua perihal vaksin dan autisme, CDC berniat meneliti masalah ini sejauh mungkin memakai metoda ilmiah yang terbaik. Dari sejumlah studi yang telah dilaksanakan perihal ini, tidak ada hubungan antara vaksin dengan autism.

\section{Pernyataan William Egan PhD., Direktur Vac- cine Research FDA di hadapan Committee on Government Reform U.S House of Repre- sentatives pada tanggal 18 Juli $2000 .^{9}$}

1. Dengan mengikuti skema imunisasi yang ada, tak ada data ataupun bukti yang menunjukkan bahaya thimerosal terhadap anak.

2. Tak ada anak yang menerima dosis toksik merkuri dari vaksin, namun FDA masih percaya untuk mengusahakan pengawet alternatif lain untuk vaksin.

3. Jumlah merkuri tidak melebihi panduan yang ditetapkan oleh FDA, ATSDR (Agency for Toxic Substances and Disease Registry) dan WHO (World Health Organization). 
Orang tua hendaknya tetap memberikan vaksinasi kepada anak-anaknya sambil menunggu pihak produsen vaksin bekerja untuk menghilangkan thimerosal dari vaksin. Risiko tidak memberikan vaksinasi jauh lebih besar dibanding dengan risiko paparan thimerosal yang belum jelas dan jauh lebih kecil jumlahnya.

\section{Beberapa cara pilihan untuk mengurangi Thimerosal dalam vaksin. ${ }^{10}$}

\section{EMEA (The European Agency for the Evaluation of} Medicinal Products) mengusulkan beberapa cara

1. Mengurangi jumlah thiomersal dalam produk akhir.

2. Menghilangkan thimerosal sama sekali.

3. Menghilangkan thimerosal tapi dengan mengganti pengawet alternatif.

Mengurangi ataupun menghilangkan thimerosal akan mempunyai dampak terhadap kualitas mikrobiologi, kelarutan, imunogenisitas, reaktogenisitas maupun stabilitas. Karena itu sebelum diterapkan cara ini perlu dilakukan studi pengembangan dan validasi dahulu, setelah semuanya dianalisis dengan kritis, perlu dilakukan uji klinis yang bertujuan untuk mengetahui dampak perubahan pada keamanan dan efikasi.

Penggantian thimerosal dengan bahan pengawet lain hanya dapat dilakukan setelah pemeriksaan yang teliti menyangkut perimbangan risiko/manfaat dengan efikasi anti-mikrobial, kompatibilitas antar antigen, bahan pembantu dan wadah vaksin serta stabilitas, keamanan dan efikasi vaksin. Sebagai contoh, barubaru ini terjadi reaksi demam yang frekuensinya berlebihan setelah thimerosal dihilangkan dari vaksin Tick-borne Encephalitis.

\section{Bagaimana pendapat WHO? ${ }^{4,11}$}

- WHO menggaris bawahi pentingnya melanjutkan pemakaian vaksin yang tersedia sekarang ini. Walaupun WHO mendukung pernyataan bersama AAP dan PHS perihal rencana menghilangkan thimerosal dari vaksin.

- Melanjutkan rekomendasi vaksin yang mengandung pengawet seperti DPT, TT dan DT, vaksin-vaksin ini telah dipakai dengan aman di dunia selama lebih dari 60 tahun dan menyelamatkan berjuta-juta anak.
- Rekomendasi dari Amerika Serikat menghindari pemakaian vaksin Hepatitis-B yang mengandung thimerosal pada bayi baru lahir tertentu, termasuk skrining ibu hamil terhadap petanda hepatitis-B. WHO menganggap penting bahwa ini bukan pilihan untuk negara berkembang karena kendala praktis dan tingginya biaya. Sebagai gantinya, WHO menganjurkan pengembangan single-dose Hepatitis-B yang tidak akan membutuhkan pengawet (misalnya kemasan vaksin dalam Uniject).

- Melanjutkan kerja sama dengan industri dan NRA (National Regulatory Authority) untuk menghilangkan thimerosal dari vaksin dalam waktu yang sesingkat-singkatnya bila sudah ditemukan alternatif thimerosal yang efektif.

- Mempelajari kemungkinan melakukan kombinasi beberapa vaksin ke dalam satu vial, sehingga jumlah thimerosal menjadi berkurang.

PT Bio Farma sebagai produsen vaksin, selalu mengikuti persyaratan produksi dan pengujian menurut WHO. Pengakuan dari WHO sudah diperoleh baik untuk vaksin bakteri maupun vaksin virus. Setiap batch vaksin dikontrol oleh Badan POM. Dua tahun sekali Bio Farma diperiksa oleh WHO, contoh vaksin diperiksa oleh laboratorium independen, sehingga kualitas produk Bio Farma selalu di bawah pemantauan Badan POM dan WHO. Dengan demikian Bio Farma selalu mengutamakan keamanan vaksin melalui kerja sama dengan WHO dan Badan POM.

\section{Daftar Pustaka}

1. Wakefield AJ, Murch SH, Anthony A dkk. Ileallymphoid-nodular hyperplasia, non-specific colitis, and pervasive development disorder in children. Lancet 1998; 35:637-41.

2. Halsey NA. Limiting infant exposure to thimerosal in vaccines and other sources of mercury. JAMA; 1999; 18:10.

3. Joint statement concerning removal of thimerosal from vaccines - United States, http://www.cdc.gov/nip/vacsafe/ concerns/thimerosal.

4. Thiomersal as a vaccine preservative, Weekly Epidemiological Record, 2000; 2.

5. Thimerosal, Questions and answers provided for the United States CDC, Atlanta, July 1999.

6. WHO Expert Committee on Biological Standardization, Technical Report Series 1990; 800.

7. Thimerosal, a mercury-containing preservative used in 
some vaccines, July 8, 1999, http://www.vaccinesafety.edu/ thimerosal.htm.

8. Thimerosal Policy questions and Answers, National Immunization Programme, http://www.cdc.gov/nip/ vacsafe/thimerosal/PolicyQ\&A.htm.

9. Statement of William Egan PhD. Acting office director, office of vaccine research and review CBER, FDA, before the committee on government reform, U.S House of
Representative, July 2000; 18.

10. Committee for proprietary medicinal products (CPMP), Points to consider on the reduction, elimination or substitution of thiomersal in vaccines, EMEA, 16 November 2000.

11. Thiomersal, children's vaccines- safety first, 8 July, 1999, http://www.who.int/vaccines-diseases/ safety/media/ pressnotethiomersal. 